\title{
Argania spinosa (L.) as a source of new and efficient green corrosion inhibitor for copper in acidic medium: a comparative study of three green compounds
}

\author{
F. Mounir, ${ }^{1}$ R. Salghi, ${ }^{2 *}$ S. Jodeh, ${ }^{3 *}$ S. El Issami ${ }^{1}$ and L. Bazzi ${ }^{1}$ \\ ${ }^{1}$ Laboratoire Matériaux et Environnement, Faculté des Sciences d'Agadir, Morocco \\ ${ }^{2}$ Laboratory of Applied Chemistry and Environment, ENSA, Université Ibn Zohr, \\ PO Box 1136, 80000 Agadir, Morocco \\ ${ }^{3}$ Department of Chemistry, An-Najah National University, P. O. Box 7, Nablus, Palestine \\ *E-mail:r.salghi@uiz.ac.ma,sjodeh@hotmail.com
}

\begin{abstract}
The inhibition effect of three green inhibitors, Argan Oil (AO), Cosmetic Argan Oil (CAO) and Argan Hulls Extract (AHE), against copper corrosion in $2 \mathrm{M} \mathrm{H}_{3} \mathrm{PO}_{4}$ containing $3 \cdot 10^{-1} \mathrm{M}$ $\mathrm{NaCl}$ solutions were evaluated using conventional weight loss, potentiodynamic polarization, and electrochemical impedance spectroscopy. The weight loss results showed that all the three green inhibitors are excellent corrosion inhibitors, electrochemical polarizations data discovered the mixed mode of inhibition and the results of electrochemical impedance spectroscopy have shown that the change in the impedance parameters, charge transfer resistance and double layer capacitance, with the change in concentration of the inhibitors employed is due to the adsorption of the molecule leading to the formation of a protective layer on the surface of copper. The values of the inhibition efficiency calculated from these techniques are in reasonably good agreement.
\end{abstract}

Keywords: Argan hulls extract, Argan oil, cosmetic Argan oil, corrosion, inhibition, copper.

Received: April 1, 2016. Published: April 19, 2016.

doi: $\underline{10.17675 / 2305-6894-2016-5-2-5}$

\section{Introduction}

Corrosion of materials has continued to receive interest in the technological world. In the field of corrosion inhibition, scientists are persistent in seeking better and more efficient ways of combating the corrosion of metals. Addition of corrosion inhibitors to the corrosion environment with respect to the other methods of corrosion inhibition has been employed [1,2]. Corrosion inhibition of materials has been the focus of research for centuries and in many cases has been well analyzed and understood [3-5]. The use of inhibitors is one of the most practical methods for protection against corrosion in acidic media $[2,6]$. Over the years, the use of chemical inhibitors has been limited because of their environmental threat, and more; recently, because of environmental regulations, Plant extracts are environmentally acceptable and readily available, in addition to being a 
renewable source for a wide range of corrosion inhibitors. Plant extracts are an incredibly rich source of naturally synthesized chemical compounds that can be extracted by simple procedures with low cost. However, synergistic (and antagonistic) effects are often expected with these mixtures of inhibitors, which may affect their efficiency [7-33]. For instance, the Argan tree, called Argania spinosa (L.) Skeels (Figure 1). Argania spinosa (L.) Skeels is a tropical plant, which belongs to the Sapotaceae family. Populations of Morocco traditionally use the fruits of A.spinosa to prepare edible oil [34]. It represents the only endemic species of the genus Argania. As an important traditional alimentary medicine, A.spinosa is a valuable potential for Moroccan. Traditionally, the Argan tree is used for many purposes. In cosmetics, Argan oil is advocated as moisturizing oil, against acne juvenile and flaking of the skin as well as for nourishes the hair [35].

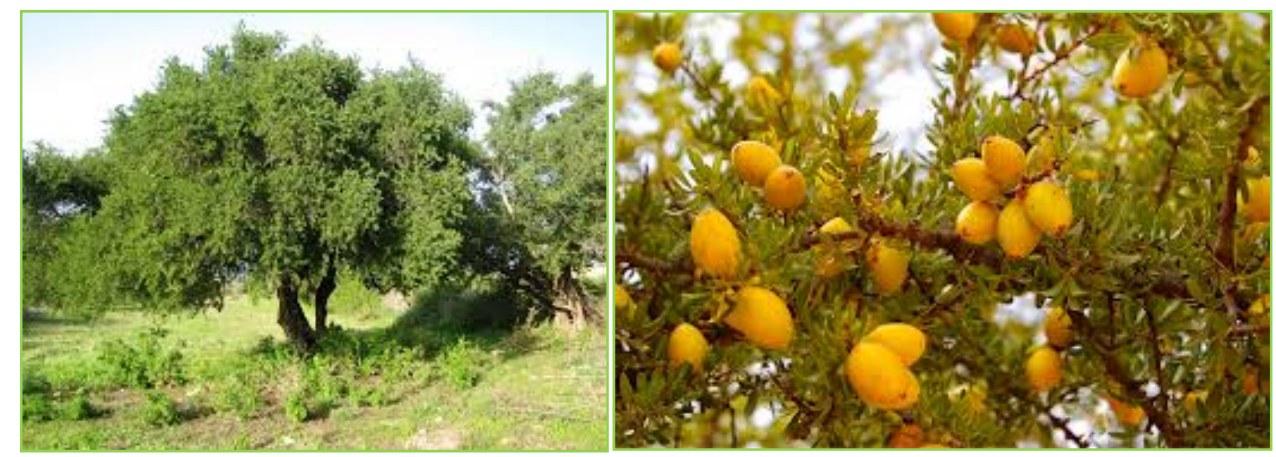

Figure 1. Argania spinosa (L.) Skeels.

The main constituents in argan oil and cosmeticargan oil were palmitic acid, oleic acid, linoleic acid, schottenol, spinasterol and $\gamma$-tocopherol [7,8]. The chemical composition of the hulls is characterized by high amount of ADF fiber [36]. The nitrogenfree hulls extract (19.5\%) is quite large and probably contains several classes of secondary metabolites such as polyphenols and saponins. Our team has isolated from the hull four saponins, 2 of which (arganine $\mathrm{M}$ and $\mathrm{N}$ ) are cited in Ref. [37]. The others are also present in the fruit pulp (arganine $\mathrm{K}$ and Mi-saponin A). These saponins have the same aglycone as that of the meal and differ only in the saccharide portion.

The aim of the present work is to investigate the inhibition efficiency of Argania spinosa extracts: argan oil, cosmetic argan oil and argan hulls extract, for the corrosion of copper in $2 \mathrm{M} \mathrm{H}_{3} \mathrm{PO}_{4}$ solution containing $3 \cdot 10^{-1} \mathrm{M} \mathrm{NaCl}$ has been studied by gravimetric method and electrochemical techniques such as potentiodynamic polarization and electrochemical impedance spectroscopy (EIS).

\section{Materials and methods}

\section{Weight loss measurements}

Gravimetric methods were conducted on copper test samples of a total surface of $12 \mathrm{~cm}^{2}$. All experiments were carried out under total immersion in $75 \mathrm{ml}$ of test solutions. Mass 
loss was recorded by an Analytical balance. Prior to each gravimetric or electrochemical experiment, the surface of the specimens was polished successively with emery paper up to 1200 grade, rinsed thoroughly with acetone and bidistilled water before plunging the electrode in the solution. Pure copper samples (99\%) were used. The experiments were carried out in $2 \mathrm{M} \mathrm{H}_{3} \mathrm{PO}_{4}$ medium containing $0.3 \mathrm{M}$ of $\mathrm{NaCl}$; it was prepared by dilution of Analytical Grade $84 \% \mathrm{H}_{3} \mathrm{PO}_{4}$ with bidistilled water and pure $\mathrm{NaCl}$.

\section{Electrochemical tests}

The current-voltage characteristics are recorded with a potentiostat PGZ100 piloted by Voltamaster software. The scan rate is $30 \mathrm{mV} / \mathrm{min}$ and the potential is ranged from cathodic to anodic potentials. Before recording each curve, the working electrode is maintained with its free potential of corrosion $E_{\text {corr }}$ for $30 \mathrm{~min}$. The polarisation curves are obtained from $-800 \mathrm{mV} / \mathrm{SCE}$ to $500 \mathrm{mV} / \mathrm{SCE}$. We used for all electrochemical tests a cell with three electrodes and double wall thermostats (Tacussel Standard CEC/TH). Saturated calomel (SCE) and platinum electrodes are used as reference and auxiliary electrodes, respectively. The working electrode is in the form of a disc from pure copper of the surface $1 \mathrm{~cm}^{2}$.

The tests were carried out in a temperature range from 298 to $323 \mathrm{~K}$. The electrochemical impedance spectroscopy (EIS) measurements are realised with the electrochemical system (Tacussel), which included a digital potentiostat model Voltalab PGZ100 computer at $E_{\text {corr }}$ after $30 \mathrm{~min}$ immersion in solution. After the determination of steady-state current at a corrosion potential, sine wave voltage $(10 \mathrm{mV})$ peak to peak, at frequencies between $100 \mathrm{kHz}$ and $10 \mathrm{mHz}$ are superimposed on the rest potential. Computer programs automatically controlled the measurements performed at rest potentials after $30 \mathrm{~min}$ of exposure at $298 \mathrm{~K}$. The impedance diagrams are given in the Nyquist representation. Experiments are repeated three times to ensure the reproducibility.

\section{Results and discussion}

\section{Weight loss method}

The effect of addition of argan oil, cosmetic argan oil and argan hulls extract tested at different concentrations on the corrosion of copper in $2 \mathrm{M} \mathrm{H}_{3} \mathrm{PO}_{4}+3 \cdot 10^{-1} \mathrm{M} \mathrm{NaCl}$ solution was studied by weight loss measurements at $298 \mathrm{~K}$ after $8 \mathrm{~h}$ of immersion period.

The corrosion rate $(W)$ and inhibition efficiency $I E_{\mathrm{w}}(\%)$ were calculated according to the Eqs. (1) and (2) respectively:

$$
\begin{gathered}
W=\frac{\Delta m}{S \cdot t} \\
I E_{\mathrm{w}}(\%)=\frac{W_{\text {corr }}-W_{\text {corr }}^{\prime}}{W_{\text {corr }}} \times 100,
\end{gathered}
$$


where $\Delta m$ is the specimen weight before and after immersion in the tested solution, $S$ is the area of the copper specimen and $t$ is the exposure time. $W_{\text {corr }}$ and $W_{\text {corr }}^{\prime}$ are the corrosion rate of copper in $2 \mathrm{M} \mathrm{H}_{3} \mathrm{PO}_{4}+3 \cdot 10^{-1} \mathrm{M} \mathrm{NaCl}$ in the absence and presence of inhibitor, respectively.

The values of percentage inhibition efficiency $I E_{\mathrm{w}}(\%)$ and corrosion rate $(W)$ obtained from weight loss method at different concentrations of inhibitors at $298 \mathrm{~K}$ are summarized in Table 1.

Table 1. Gravimetric results of copper in acid without and with addition of the inhibitors at various contents $(t=8 \mathrm{~h}, T=298 \mathrm{~K})$.

\begin{tabular}{ccccc}
\hline Inhibitors & Concentration $\mathbf{( g / L )}$ & $\boldsymbol{W}^{\prime}\left(\mathbf{m g} \cdot \mathbf{h}^{\mathbf{- 1}} \cdot \mathbf{d m}^{-\mathbf{2}}\right)$ & $\boldsymbol{I} \boldsymbol{E}_{\mathbf{w}} \mathbf{( \% )}$ & $\boldsymbol{\theta}$ \\
\hline Blank & 0 & 162 & - & - \\
\hline \multirow{4}{*}{ AO } & 0.5 & 105 & 35 & 0.35 \\
& 1 & 079 & 51 & 0.51 \\
& 2 & 070 & 57 & 0.57 \\
& 4 & 060 & 63 & 0.63 \\
& 6 & 044 & 73 & 0.73 \\
\hline \multirow{3}{*}{ CAO } & 0.5 & 073 & 55 & 0.55 \\
& 1 & 062 & 62 & 0.62 \\
& 2 & 050 & 69 & 0.69 \\
& 4 & 026 & 84 & 0.84 \\
AHE & 6 & 016 & 90 & 0.90 \\
& 0.5 & 84 & 48 & 0.48 \\
& 1 & 71 & 56 & 0.56 \\
& 2 & 58 & 64 & 0.64 \\
& 4 & 34 & 79 & 0.79 \\
\hline
\end{tabular}

It is very clear that the three green inhibitors inhibits the corrosion of copper in $2 \mathrm{M}$ $\mathrm{H}_{3} \mathrm{PO}_{4}+3 \cdot 10^{-1} \mathrm{M} \mathrm{NaCl}$ solution, at all concentrations used in this study, and the corrosion rate $\left(W^{\prime}\right)$ decreases continuously with increasing three inhibitors concentration at $298 \mathrm{~K}$. Indeed, corrosion rate values of copper decrease when the inhibitor concentration increases while $I E_{\mathrm{w}}(\%)$ values of $\mathrm{CAO}, \mathrm{AO}$ and $\mathrm{AHE}$ increase with the increase of the concentration, suggesting that the number of molecules adsorbed of the three inhibitors were increased over the copper surface, blocked the active sites of acid attack and thereby protecting the metal from accelerated corrosion attack. This is also confirmed by Figure 2. The maximum $I E_{\mathrm{w}}(\%)$ of COA, AO and AHE respectively are $73 \%, 90 \%$ and $91 \%$ at $6 \mathrm{~g} / \mathrm{L}$. 


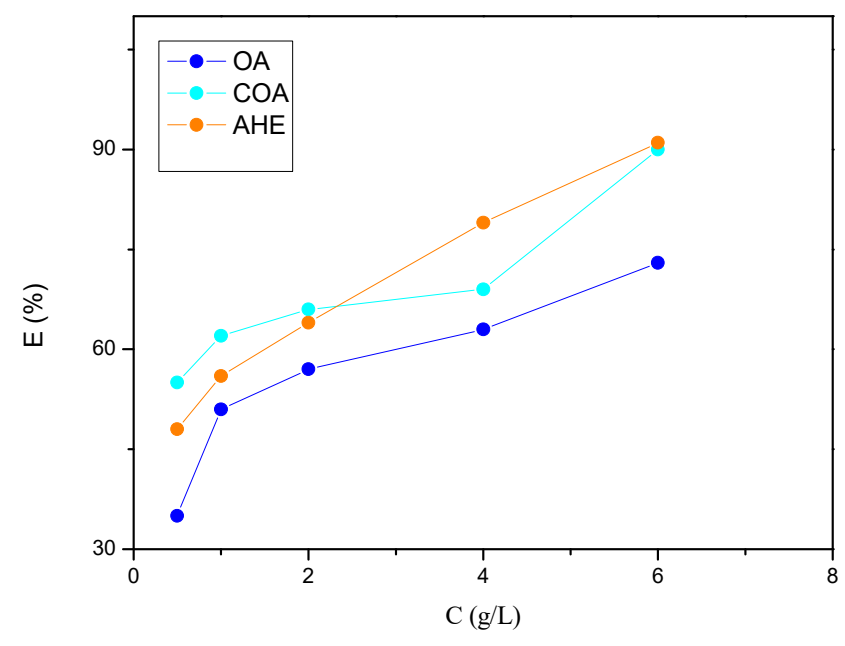

Figure 2. Variation of inhibition efficiency $\left(E_{\mathrm{w}}\right)$ of corrosion of copper in $2 \mathrm{M} \mathrm{H}_{3} \mathrm{PO}_{4}+3 \cdot 10^{-1} \mathrm{M}$ $\mathrm{NaCl}$ in the presence of three green inhibitors.

\section{Polarization curves}

Figures 2,3 and 4 show the potentiodynamic polarization curves for copper in $2 \mathrm{M}$ $\mathrm{H}_{3} \mathrm{PO}_{4}+3 \cdot 10^{-1} \mathrm{NaCl}$ solution in the absence and presence of different concentrations of $\mathrm{AO}, \mathrm{CAO}$ and $\mathrm{AHE}$ respectively. The corrosion parameters including corrosion current densities $\left(I_{\text {corr }}\right)$, corrosion potential $\left(E_{\text {corr }}\right)$, cathodic Tafel slope $\left(\beta_{\mathrm{c}}\right)$, anodic slop $\left(\beta_{\mathrm{a}}\right)$ and inhibition efficiency $(I E \%)$ are listed in Table 2.

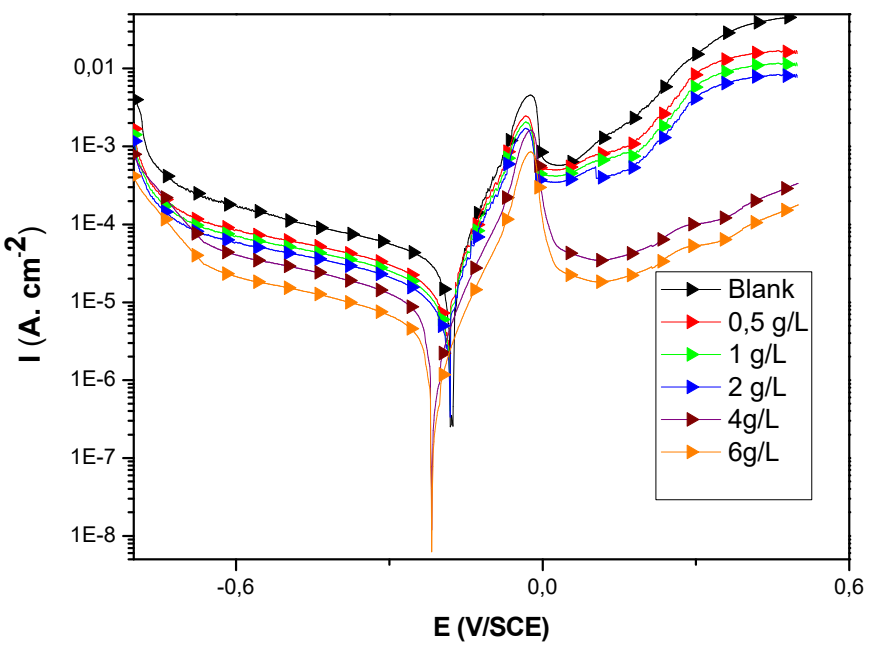

Figure 3. Cathodic and anodic polarisation curves of copper in $\left(2 \mathrm{M} \mathrm{H}_{3} \mathrm{PO}_{4}+3 \cdot 10^{-1} \mathrm{M} \mathrm{NaCl}\right)$ at different concentrations of AO. 


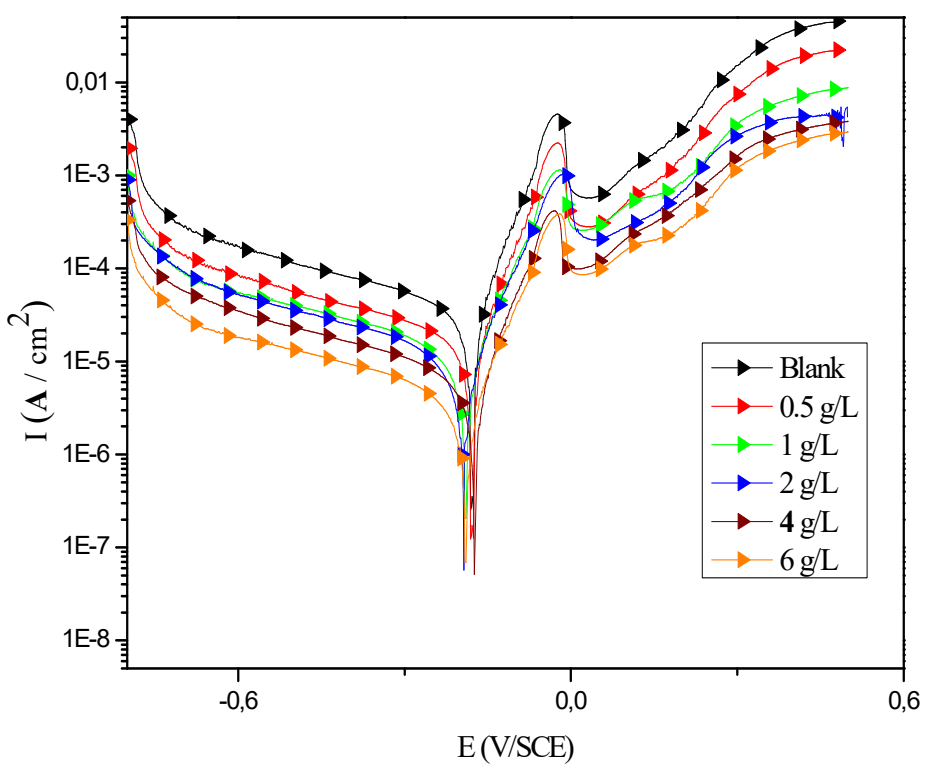

Figure 4. Cathodic and anodic polarisation curves of copper in $\left(2 \mathrm{M} \mathrm{H}_{3} \mathrm{PO}_{4}+3 \cdot 10^{-1} \mathrm{M} \mathrm{NaCl}\right)$ at different concentrations of CAO.

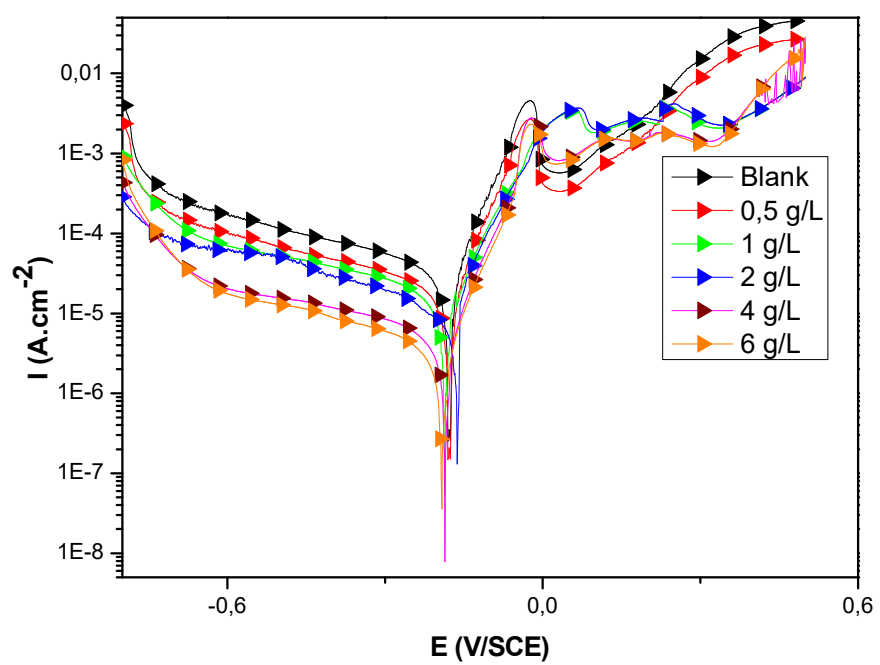

Figure 5. Cathodic and anodic polarisation curves of copper in $\left(2 \mathrm{M} \mathrm{H}_{3} \mathrm{PO}_{4}+3 \cdot 10^{-1} \mathrm{M} \mathrm{NaCl}\right)$ at different concentrations of AHE.

Inspection of the Figures 3-6 reveals that the values of $E_{\text {corr }}$ were affected and slightly changed by the addition of AO, CAO and AHE. This indicates that these inhibitors act as mixed-type inhibitors. The slopes of anodic and cathodic Tafel lines ( $\beta \mathrm{a}$ and $\beta \mathrm{c}$ ) were slightly changed (Tafel lines are parallel) on increasing the concentration of the tested 
compounds which indicates that there is no change of the mechanism of inhibition in the presence and absence of inhibitors [38].

Table 2. Electrochemical parameters of copper at various concentrations of AO, CAO and AHE in $2 \mathrm{M}$ $\mathrm{H}_{3} \mathrm{PO}_{4}+3 \cdot 10^{-1} \mathrm{M} \mathrm{NaCl}$ and corresponding inhibition efficiency.

\begin{tabular}{|c|c|c|c|c|c|c|c|}
\hline & $\begin{array}{c}\text { Concentration } \\
(\mathrm{g} / \mathrm{L})\end{array}$ & $\begin{array}{c}E_{\text {corr }} \\
(\mathrm{mV} / \mathrm{SCE})\end{array}$ & $\begin{array}{c}I_{\text {corr }} \\
\left(\mu \mathrm{A} / \mathbf{c m}^{2}\right)\end{array}$ & $\begin{array}{c}\beta \mathbf{a} \\
(\mathrm{mV} / \mathrm{dec})\end{array}$ & $\begin{array}{c}\text { Mean value } \\
\text { of } \boldsymbol{\beta}_{\mathrm{a}} \\
(\mathrm{mV} / \mathrm{dec})\end{array}$ & $\begin{array}{c}\beta_{\mathrm{c}} \\
(\mathrm{mV} / \mathrm{dec})\end{array}$ & $\begin{array}{c}I E \\
(\%)\end{array}$ \\
\hline Blank & 0 & -177 & 36 & 68 & $65 \pm 6$ & -297 & - \\
\hline \multirow{5}{*}{ CAO } & 0.5 & -181 & 17 & 59 & \multirow{5}{*}{$65 \pm 6$} & -439 & 53 \\
\hline & 1 & -192 & 14 & 69 & & -487 & 61 \\
\hline & 2 & -192 & 21 & 68 & & -462 & 67 \\
\hline & 5 & -179 & 7 & 67 & & -486 & 81 \\
\hline & 6 & -191 & 4 & 71 & & -401 & 89 \\
\hline \multirow{5}{*}{$\mathrm{AO}$} & 0.5 & 184 & 23 & 57 & \multirow{5}{*}{$64 \pm 5$} & -280 & 36 \\
\hline & 1 & -179 & 17 & 62 & & -350 & 53 \\
\hline & 2 & -176 & 14 & 63 & & -350 & 61 \\
\hline & 5 & -210 & 10 & 69 & & -415 & 72 \\
\hline & 6 & -209 & 6 & 71 & & -350 & 84 \\
\hline \multirow{5}{*}{ AHE } & 0.5 & -180 & 19 & 50 & \multirow{5}{*}{$52 \pm 4$} & -415 & 47 \\
\hline & 1 & -188 & 17 & 51 & & -401 & 53 \\
\hline & 2 & -170 & 12 & 48 & & -399 & 64 \\
\hline & 5 & -188 & 6 & 56 & & -420 & 83 \\
\hline & 6 & -188 & 3 & 54 & & -310 & 91 \\
\hline
\end{tabular}

The percentage of inhibition efficiency (IE\%) were calculated from polarization measurements using the relation:

$$
I E \%=\left(1-\frac{I_{\text {corr }}^{\prime}}{I_{\text {corr }}}\right) \times 100,
$$

where $I_{\text {corr }}$ and $I_{\text {corr }}^{\prime}$ are the uninhibited and inhibited current densities, respectively.

From electrochemical polarisation measurements, it is clear that the addition of the different inhibitors leads to a decrease in the cathodic current densities. Examination of the $I E \%$ values given in Table 2, reveals that inhibition efficiency increases with an increase in the concentration of additives. The increase in inhibition efficiency observed at higher inhibitors concentration indicates that more inhibitors molecules are adsorbed on the metal surface thus providing wider surface coverage and these compounds are acting as 
adsorption inhibitors. We remark that the corrosion current densities were more significantly reduced in the presence of different inhibitors. The best efficiencies obtained in the presence of CAO, $\mathrm{AO}$ and $\mathrm{AHE}$ respectively are $89 \%, 84 \%$ and $91 \mathrm{~g} / \mathrm{L}$ at $6 \mathrm{~g} / \mathrm{L}$.

\section{Electrochemical impedance measurements}

Figures 6-8 show Nyquist plots for copper in $2 \mathrm{M} \mathrm{H}_{3} \mathrm{PO}_{4}+3 \cdot 10^{-1} \mathrm{M} \mathrm{NaCl}$ in absence and presence of different concentrations of $\mathrm{AO}, \mathrm{CAO}$ and $\mathrm{AHE}$ in the concentration range $0.5 \mathrm{~g} / \mathrm{L}$ to $6 \mathrm{~g} / \mathrm{L}$ at $298 \mathrm{~K}$.

Nyquist plots consist of one capacitive loop with one time constant. The charge transfer resistance values $\left(R_{\mathrm{t}}\right)$ are calculated from the difference in impedance at lower and higher frequencies, as described elsewhere [39]. To obtain the double layer capacitance $\left(C_{\mathrm{dl}}\right)$ the frequency at which the imaginary part of the impedance is maximum $\left(-Z_{\mathrm{img}}\right)$ maxis found and $C_{\mathrm{dl}}$ values are calculated from the following equation [40]:

$$
C_{\mathrm{dl}}=\frac{1}{\omega \cdot R_{\mathrm{t}}},
$$

where $\omega=2 \pi f_{\max }$.

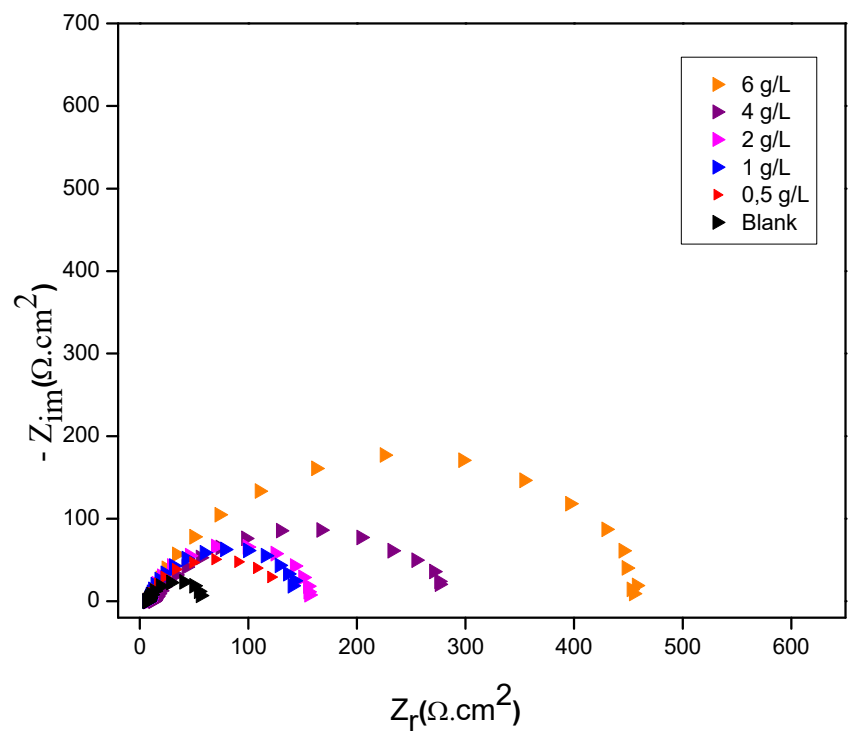

Figure 6. Nyquist diagrams for copper electrode in $\left(2 \mathrm{M} \mathrm{H}_{3} \mathrm{PO}_{4}+0.3 \mathrm{M} \mathrm{NaCl}\right)$ with and without $\mathrm{CAO}$ after $30 \mathrm{~min}$ of immersion at $E_{\text {corr }}$. 


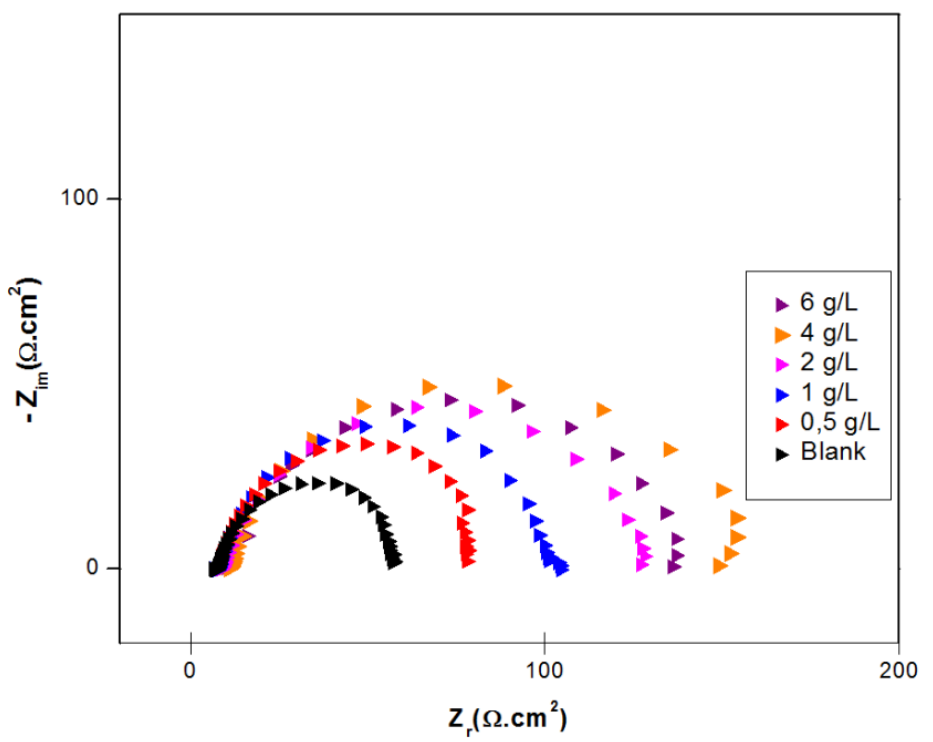

Figure 7. Nyquist diagrams for copper electrode in $\left(2 \mathrm{M} \mathrm{H}_{3} \mathrm{PO}_{4}+0.3 \mathrm{M} \mathrm{NaCl}\right)$ with and without $\mathrm{AO}$ after 30 min of immersion at $E_{\text {corr. }}$.

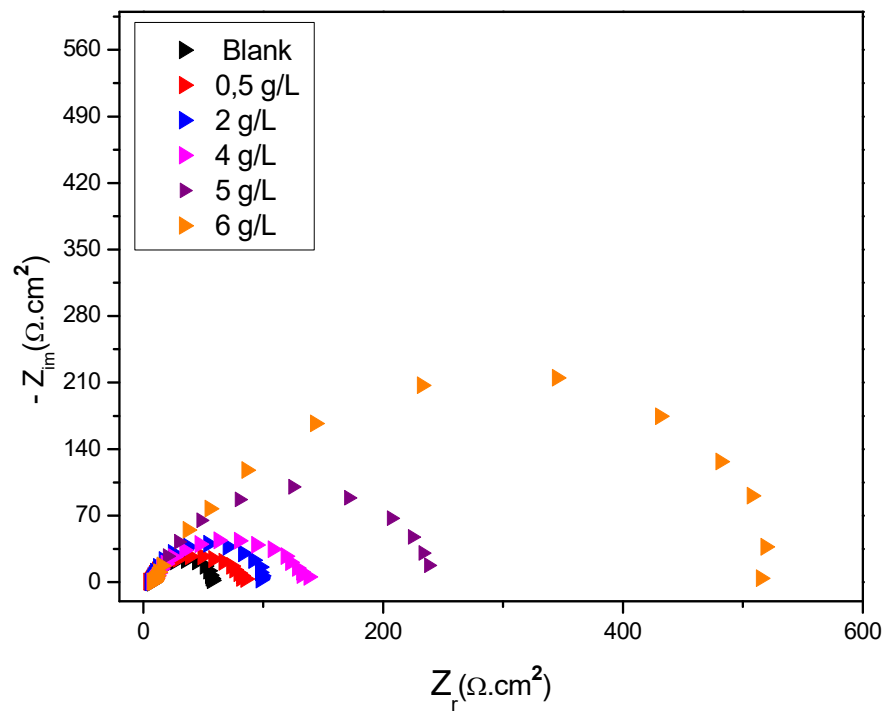

Figure 8. Nyquist diagrams for copper electrode in $\left(2 \mathrm{M} \mathrm{H}_{3} \mathrm{PO}_{4}+0.3 \mathrm{M} \mathrm{NaCl}\right)$ with and without $\mathrm{AHE}$ after $30 \mathrm{~min}$ of immersion at $E_{\text {corr }}$.

The interpretation of Nyquist Figures 6-8 allow to determine the electrochemical parameters of the copper electrode and to acquire information about the corrosion process and mechanism. Data in Table 3 shows that these compounds obviously inhibit the corrosion of copper in $2 \mathrm{M} \mathrm{H}_{3} \mathrm{PO}_{4}+3 \cdot 10^{-1} \mathrm{M} \mathrm{NaCl}$. The inhibition efficiency increased by increasing the concentration of the studied inhibitors. The inhibition efficiency is calculated using charge transfer resistance from Equation 4 [41]: 


$$
E_{\mathrm{Rt}}(\%)=\frac{R_{\mathrm{t}}-R_{\mathrm{t}}^{0}}{R_{\mathrm{t}}} \times 100,
$$

where $R_{\mathrm{t}}$ and $R_{\mathrm{t}}^{0}$ are the charge transfer resistances in inhibited and uninhibited solutions respectively.

Table 3. Impedance parameters for corrosion of copper in acid at various contents of AO, COA and AHE.

\begin{tabular}{|c|c|c|c|c|c|}
\hline & $\begin{array}{c}\text { Concentration } \\
(\mathrm{g} / \mathrm{L})\end{array}$ & $R_{\mathrm{t}}\left(\Omega \cdot \mathrm{cm}^{2}\right)$ & $f_{\max }(\mathrm{Hz})$ & $C_{\mathrm{dl}}\left(\mu \mathrm{F} / \mathrm{cm}^{2}\right)$ & $I E_{\mathrm{Rt}}(\%)$ \\
\hline Blank & 0 & 51 & 63 & 49 & - \\
\hline \multirow{5}{*}{$\mathrm{CAO}$} & 0.5 & 120 & 44 & 30 & 57 \\
\hline & 1 & 141 & 40 & 28 & 64 \\
\hline & 2 & 152 & 38 & 27 & 67 \\
\hline & 5 & 281 & 22 & 25 & 82 \\
\hline & 6 & 460 & 15 & 23 & 89 \\
\hline \multirow{5}{*}{$\mathrm{AO}$} & 0.5 & 80 & 47 & 42 & 37 \\
\hline & 1 & 100 & 45 & 35 & 50 \\
\hline & 2 & 121 & 44 & 30 & 59 \\
\hline & 5 & 150 & 40 & 26 & 67 \\
\hline & 6 & 180 & 39 & 23 & 72 \\
\hline \multirow{5}{*}{ AHE } & 0.5 & 96 & 50 & 33 & 47 \\
\hline & 1 & 111 & 46 & 32 & 54 \\
\hline & 2 & 146 & 41 & 27 & 65 \\
\hline & 5 & 255 & 30 & 22 & 80 \\
\hline & 6 & 510 & 14 & 21 & 90 \\
\hline
\end{tabular}

By increasing the inhibitors concentration the $R_{\mathrm{t}}$ values increase but $C_{\mathrm{dl}}$ values decrease. Characterization of the adsorption and desorption and film formation on the metal electrode surface may be studied by determining its capacitance $C_{\mathrm{dl}}$. The decrease in the $C_{\mathrm{dl}}$ value is due to the adsorption of the inhibitors on the copper surface [42]. The best efficiencies obtained in the presence of CAO, AO and AHE respectively are $89 \%, 72 \%$ and $90 \%$ at $6 \mathrm{~g} / \mathrm{L}$. The results obtained from the electrochemical impedance spectroscopy (EIS) were in good agreement with those obtained from the polarization technique and weight loss method for the three compounds.

A comparison may be made between inhibition efficiency $I E(\%)$ values obtained by different methods (weight loss, polarization curves and EIS methods). Figure 9 shows a histogram that compares the $I E(\%)$ values obtained. One can see that whatever the method used, no significant changes are observed in $I E(\%)$ values. We can then conclude that there is a good correlation with the three methods used in this investigation at all tested concentrations and that inhibitors are efficient corrosion inhibitors. 


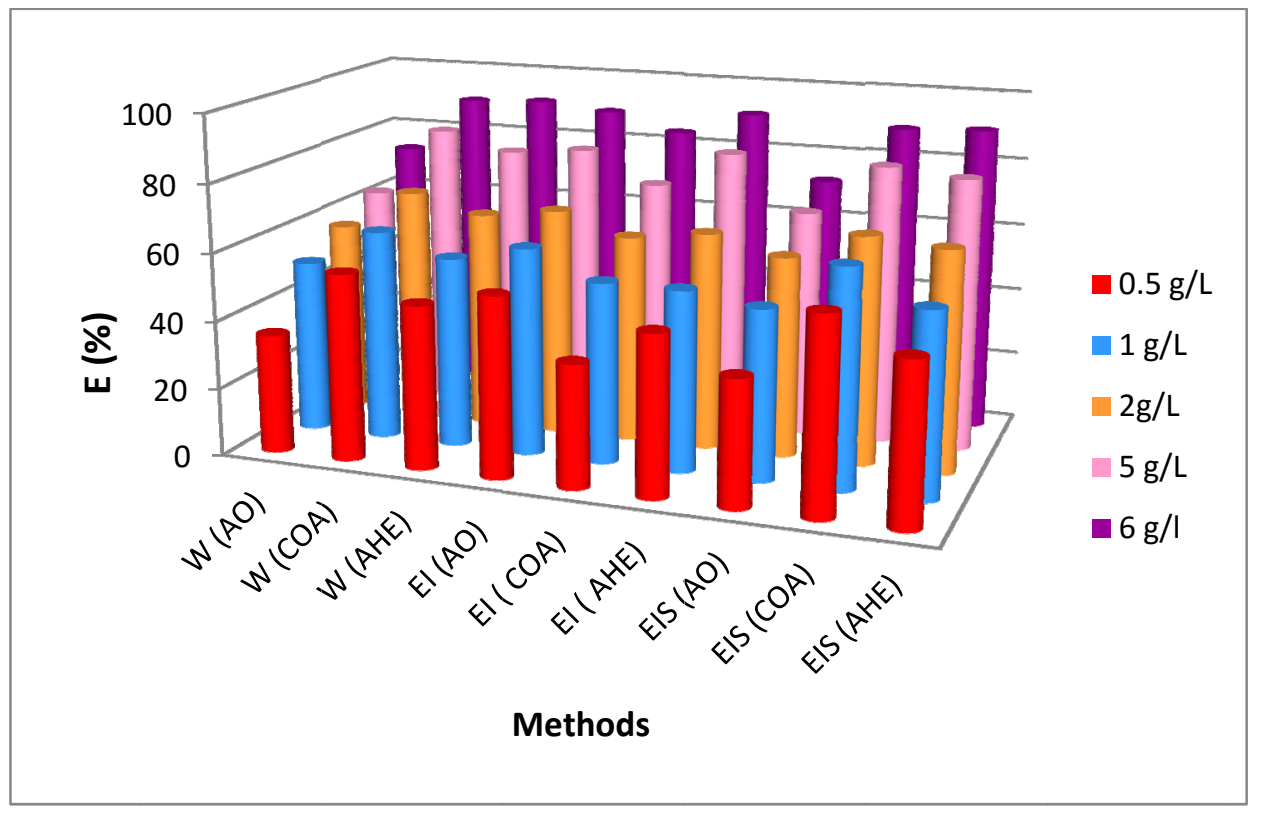

Figure 9. Comparison of inhibition efficiency $I E(\%)$ values obtained by weight loss (W), polarization (EI) and EIS methods.

\section{Conclusion}

The protection effectiveness with the addition of all the three inhibitors increases with the increase of the inhibitor concentration. In addition, for all the methods studied the maximum $I E(\%)$ obtained at $6 \mathrm{~g} / \mathrm{L}$. Polarization measurements have shown that they all have acted as mixed type corrosion inhibitors, retarding mainly dissolution of copper in $2 \mathrm{M} \mathrm{H}_{3} \mathrm{PO}_{4}+3 \cdot 10^{-1} \mathrm{NaCl}$. The results of the weight loss, electrochemical polarizations and EIS were all in very good agreement to support the above conclusions. And these three green inhibitors possessed all the characteristics which the industries require for potential inhibitor applications.

\section{References}

1. K. Orubite-Okorosaye, I.R. Jack, M. Ochei and O. Akaranta, J. Appl. Sci. Environ. Manage., 2007, 11, 27.

2. M.A. Malik, M.A. Hashim, F. Nabi, S.A. Al-Thabaiti and Z. Khan, Int. J. Electrochem. Sci., 2011, 6, 1927.

3. M.M. Caroline, P. Christian, C.S. Hannes, K. Boris and A.A. Ilhan, Langmuir, 2008, 24, 14269.

4. S.A.A. El-Maksoud, Int. J. Electrochem. Sci., 2008, 3, 528.

5. M.M. Antonijevic and M.B. Petrovi, Int. J. Electrochem. Sci., 2008, 3, 1.

6. I.A. Zaafarany and H.A. Ghulman, Int. J. Corros. Scale Inhib., 2013, 2, 82. doi: 10.17675/2305-6894-2013-2-2-082-091

7. F. Mounir, S. El Issami, Lh. Bazzi, A. ChihabEddine, M. Belkhaouda, L. Bammou, R. Salghi, O. Jbara and L. Bazzi, J. Chem. Bio. Phy. Sci. Sec. C., 2014, 4, 2249. 
8. F. Mounir, S. El Issami, Lh. Bazzi, O. Jbara, A. ChihabEddine, M. Belkhaouda, L. Bammou, R. Salghi and L. Bazzi, Mor. J. Chem., 2014, 2, 33.

9. F. Mounir, S. El Issami, Lh. Bazzi, O. Jbara, A. ChihabEddine, M. Belkhaouda, L. Bammou, R. Salghi and L. Bazzi, J. Advances in Chemistry, 2014, 4, 2321-807X.

10. F. Mounir, S. El Issami, Lh. Bazzi, O. Jbara, A. ChihabEddine, M. Belkhaouda, L. Bammou, R. Salghi and L. Bazzi., J. Appl. Chem. (Lumami, India), 2014, 3, 885.

11. F. Mounir, S. El Issami, Lh. Bazzi, R. Salghi, L. Bammou, L. Bazzi1, A. ChihabEddine and O. Jbara, Int. J. Res. Rev. Appl. Sci., 2012, 2,10.

12. A. Bouyanzer, L. Majidi and B. Hammouti, Bull. Electrochem., 2006, 22, 321.

13. A. Chetouani, B. Hammouti and M. Benkaddourm, Pigment \& Resin Technol., 2004, 33, 26.

14. M. Bendahou, M. Benabdellah and B. Hammouti, Pigment \& Resin Technol., 2006, 35 , 95.

15. E. Chaieb, A. Bouyanzer, B. Hammouti, M. Benkaddour and M. Berrabah, Trans. of SAEST., 2004, 39, 58.

16. E. El-Ouariachi，J. Paolini，M. Bouklah, A. Elidrissi， A. Bouyanzer，B. Hammouti, J.M. Desjobert and J. Costa, Acta Metall. Sin., 2010, 23, 13.

17. O. Ouachikh, A. Bouyanzer, M. Bouklah, J.M. Desjobert, J. Costa, B. Hammouti and L. Majidi, Surf. Rev. and Letters., 2009, 16, 49.

18. M. Benabdellah, M. Benkaddour, B. Hammouti, M. Bendahou and A. Aouiti, Appl. Surf. Sci., 2006, 252, 6212.

19. A. Bouyanzer and B. Hammouti, Pigment \& Resin Technol., 2004, 33, 287.

20. B. Zerga, M. Sfaira, Z. Rais, M. Ebn Touhami, M. Taleb, B. Hammouti, B. Imelouane and A. Elbachiri, Mater. Tech., 2009, 97, 297.

21. Z. Faska, L. Majidi, R. Fihi, A. Bouyanzer and B. Hamouti, Pigment \& Resin Technol., 2007, 36, 293.

22. E. Chaieb, A. Bouyanzer, B. Hammouti and M. Benkaddour, Appl. Surf. Sci., 2005, 246, 199.

23. Z. Faska, A. Bellioua, M. Bouklah, L. Majidi, R. Fihi, A. Bouyanzer and B. Hammouti, Monatsh. Chem, 2008, 139, 1417.

24. K. Olusegun, A.O. Abiola and A. James, Corros. Sci., 2010, 52, 661.

25. O.K. Abiola, J.O.E. Otaigbe and O. J. Kio, Corros. Sci., 2009, 51, 1879.

26. O.K. Abiola and N.C. Oforka, Scientia Africana, 2003, $2,82$.

27. A.Y. El-Etre, M . Abdallah and Z.E. El-Tantawy, Corros. Sci., 2005, 47, 385.

28. L. Valek and S. Martinez, Mater. Lett., 2007, 61, 148.

29. M. Znini, L. Majidi, A. Bouyanzer, J. Paolini, J.M. Desjobert, J. Costa and B. Hammouti, Arabian J. Chem., 2012, 5, 467.

30. A.Y. El-Etre, J. Colloid Interface Sci., 2007, 314, 578.

31. A. Bouyanzer, B. Hammouti and L. Majidi, Mater. Lett., 2006, 60, 2840.

32. F. Mounir， S. El Issami， Lh. Bazzi， R. Salghi， N. Abidi， S. Jodeh， L. Bazzi and A. Chihab Eddine, J. Mater. Environ. Sci., 2015, 6, 2066. 
33. F. Khallouki, B. Spiegelhalder, H. Bartsch and R.W. Owen, Afr. J. Biotechnol., 2005, 4, 381 .

34. F. Henry, L. Danoux, G. Pauly and Z. Charrouf, Patent EP 1430900 (2004).

35. Valuation of the fruit of the Argan tree; Argan oil: quality, diversification (Research Component Contract No. AR05A061P704 between Social Development Agency (Morocco) and Agropolis International, Proposed EU / MEDA / ADS "Support for improving the employment situation of rural women and sustainable management of the argan tree in the southwest of Morocco", 2009.

36. A. Alaoui, Z. Charrouf, M. Soufiaoui, V. Carbone, A. Malorni, C. Pizza and S. Piacente, J. Agric. Food Chem., 2002, 50, 4600.

37. A.S. Fouda, M.A. El-Morsy, A.A. El-Barbary and L.E. Lamloum, Int. J. Corros. Scale Inhib., 2016, 5, no. 2, 112.

38. S.S. Abdel-Rehim, M.M. Ibrahim and K.F. Khaled, J. Appl. Electrochem., 1999, 29, 593.

39. M. Bouklah, A. Ouassini, B. Hammouti and A. El Idrissi, Appl. Surf. Sci., 2005, 50, 250.

40. K. Tebbji, I. Bouabdellah, A. Aouniti, B. Hammouti, H. Oudda, M. Benkaddour and A. Ramdani, Mat. Lett., 2007, 61, 799.

41. I.L. Rozenfeld, Corrosion Inhibitors, McGraw-Hill, New York, 1981. 